\title{
Lies and Life: The Other Italians
}

\author{
Charles Lemert
}

From Vico to Gramsci-not to mention Croce, Pareto, and Mosca-Italy has been always close to the heart of modern social theory. If one were to stretch the point to include Augustine of Hippo's formative years in Milan, one might even say that the seeds of critical social theory as it came to be were planted in Augustine's City of God which was in effect, if not design, a transcendental critical theory of Rome's collapse before Alaric's invasion in 410 C.E.

Wherever one locates the origins of Italian social thought it would be hard to deny that Gramsci, in particular, is the principal figure in the modern era. Prison Notebooks ranks as a masterwork of critical theory and a work well ahead of its time (arguably more subtle, if less systematic, than the early writings of Adorno and Horkheimer). At the very least, the notebooks did more, and did it earlier, to lay down the working principles of a comprehensive outline of the cultural crisis of the modern State than even the parallel movement in Germany. Not only that, but Gramsci's theory of cultural hegemonies was a precursor of Althusser's famous essay on the cultural effects of State power and, at the least a marker on the way to, if not a direct source of, Foucault's later theories of biopower and governmentality. More recently, Hardt and Negri's Empire, while of mixed Italian heritage, calls attention to the value of Gramsci's thinking in the renewal of Italian social theory upon its foundational ties to the younger Marx's revision of left Hegelianism. The, to me, inexplicable success of Empire goes mostly to demonstrate the greater originality of Gramsci's ideas. Where Gramsci was careful (a care required to confound his prison censors), Hardt and Negri are breathtakingly careless in their silly misappropriations of Foucault and Deleuze.

Still, it is good that attention has turned to the Italian traditions which, if we are to be fully serious about them, requires the study of two who by the refinements of their expositions represent the Italian way in a fashion reminiscent of Gramsci's. These, then, are the other Italians_-Umberto Eco and Giorgio Agamben. Perhaps because, like Vico before them, both Eco and Agamben started out as medievalists (which is to say, classicists), their writings are fraught with riddles. It should be said, however, that like Gramsci, whose writings were necessarily over-coded, their mystery stories are meant to be solved. Then too where they are inscrutable it is less painfully for irony's sake, as in the earlier writings of Derrida and the two great books of Deleuze and Guattari. Eco and Agamben incline toward the mysterious and do so not for their own religious purposes but because of the religious questions intrinsic to medieval thought and culture; in particular, they address two of the most inscrutable mysteries of the boundaries between the human and the nature-mysteries, whether theological or existential, all humankind must confront: lies and life. How are we to live if things are as they seem or as they are said to be? Do we have any real alternative but to pick from the forbidden tree of knowledge at the cost of our idealize nature?

In A Theory of Semiotics (1979), Eco makes the remarkable observation that "every time there is signification there is the possibility of lying." More fully, Eco states (58-59):

Every time there is [the] possibility of lying, there is a sign-function: which is to signify (and then to communicate) something to which no real state of things corresponds. A theory of codes must study everything that can be used to lie.

One clue as to what he is driving at is in the title of the 1968 Italian edition of Theory of Semiotics: La struttura assente (The absent structure) which of course is a reference to Ferdinand de Saussure's classical statement of the elements of semiology. The structures of all signifying systems, including spoken languages, are organized not upon the correspondence between signs and things in the world but in a social contract by which the effective communication of meanings depends on an absent structure in the form of any given system of signs and rules 
governing their use. The color red associated with traffic systems depends on the competent understanding of green and, in most instances, yellow. Some may trust that the red light expresses a danger ahead, but the system itself is, as Saussure put it, arbitrary in the sense that whatever a culture may associate with red, green has no necessarily relation to safety. Stop/go constitute in elemental social agreement as to movement in traffic of all kinds-a system articulated by means of lights or signs of other kinds that to the sober express what is actually a fine-tuned, crucial rule concerning the right or wisdom of moving in a certain direction. The directive is not in the real world, but the system itself such that you might say that red or stop is the absence-of-green, hence: not-go. Both cannot be meaningfully lit at once.

Though Eco's book was meant as a technical theory of sign-functions or semiotics, the theory, embedded as it is in Saussurian linguistics, has far ranging implications to the current situation. For one, Eco picks up the implications of Saussure's distinction between parole/langue_-speech/language_ — which stands behind the more contemporary distinction message/code or practice/competence. Parole/langue invites the conclusion that communicative performance draw upon the absent-to-the-performance competences which are the contents of the absent structures - and by extension stand behind any and all dynamic theories of the relation of praxis to theory. Contrary to the common practice of setting agencies as somehow at odds with structures, meaningful actions of all kinds are always and of necessity engaged with structures which are, as Giddens has put it, resources for as much as they restrictions on actions. The association, if not direct link, to Gramsci's nuanced idea of praxis as always distorted-yet, still able to revolutionize the world through and after deep reflection on limits of praxis. The link, more direct, to Marx's theory of human value articulated against the mode of production that also constrains human labor is more apparent - and, by the way, one of the unsolved problems among those who would understand the sources of Saussurian linguistics which are, at once (but unglossed), Durkheim and Marx. On the same point, Eco does, and aptly, refer to Vico whoseScienza Nuova (1725-1730) includes the idea, as Eco puts it (254), that "languages rise as poetic inventions and are only accepted by convention afterward." Performance is the resource of competence.

Eco's theory of lies applies, however, to very much more than a technical theory of codes and meanings. In one aspect, one can draw from Eco a strong theory that helps to reframe the debate among rival theorists of culture. To what extent are socially composed cultures appropriated for use in the systematic distortions offered in the guise of truth-telling _ as, for an example (also found in Gramsci's essay on Americanism), liberal modernity's cult of individualism and free-markets as the bluff meant to cover the empty hand dealt by capitalism's furtively systematic exploitations of technically free labor? Can there ever be a robust theory of cultural meanings without a theory of lies?

In another aspect, a theory of lies can lead to an equally strong theory of all forms of human-life practices. How else does it happen that lives are lived in the short-run of practical needs and wants when, in the long-run, actions are justified by appeals to realities that cannot be as they are represented? Real structures, absent though they are, are by their nature distortions of the realities they impose. If so, then is it not the freedom of actors to lie in respect to their motivations_ — and to lie as much to themselves as to others (and especially to those in structured authority) — that is the indispensable tactic in what possibilities there might be for change. Communication in its broadest sense is a coming to terms with the possibility of lying in order to contend with, get around, survive, and resist the false realities imposed by hegemonic orders. Our truth-telling, such as it is, is always without exception at least a lie of omission and, in crucial political instances, a sin of commission. The intentions we (s'il y en un) profess in practical, short-run actions is a poetics of the situation at hand that (like Gramsci's prison writings) are over-coded in the face of censors and police of all kinds — a reach beyond the truth of things at hand based on the practical wisdom that social things imposed are by their nature distorted - that is, are down-right lies in and of themselves. In a word, lies are necessary to life. Those who imbibe unflinchingly the structurally sanctioned truth-tellings of, say, the State are condemned to live as machines. The genius of children is in their wisdom that their independence from parental authority requires make-believe in the early years and outright lies as they grow older.

Lies, thus, are essential to life_-and this is where Giorgio Agamben comes in. Agamben's most famous and influential book is Homo Sacer: Sovereign Power and Bare Life ([1995] 1998). Much as Eco does in respect to what every one knows on some level (that truth is a lie), so Agamben does with respect to bare life (that human life is first and foremost animal and more than animal). The twist for Agamben is that bare life is at the original basis of politics - hence (in a critical refiguring of Foucault) biopolitics. "The fundamental activity of sovereign power," says Agamben (181), "is the production of bare life as originary political element and as threshold of articulation between nature and culture, zo• and bios." 'The two Greek words for life-zo• and bios-Agamben takes from Aristotle's (and 
the Greek language's) distinction between the mere living common to all living things ( $\mathrm{zo} \cdot$ ) and the more categorical concept of life (bios) in the sense of belonging to a group. Here begins Agamben's influential contribution to the debate over sovereign power and its relation to citizenship — a debate that goes back at least to the writ of habeas corpus in 1679, when English law modified the terms of the Magna Carta (1215) to assure that no man can be judged without being brought, bodily, before the judiciary. The question at issue is the state of corpus, the natural body, as a sign of elemental human liberty — a question that today stands behind the uncertain rights of children not to be tried as adults, of the mentally incapacitated not to be executed, of political prisoners to be brought to trial, of the poor to be properly represented. Agamben thus adds (125). "Corpus is a two-faced being, the bearer both of subjection to sovereign power and of individual freedom." In other words, the sovereign is the entity to which is ascribed the authority to guarantee the liberties of the citizen up to the point at which the State judges those freedoms a threat to the State itself. This, many will recognize, is the theme taken up today in the rehabilitation of Carl Schmitt's state of exception which, in time, turned upon the question of the State power of the Nazis who in 1933 suspended article 48 of the Weimar constitution in order to protect the "German people" —in order, that is, as it could already then be seen: to create the F.hrer as at once the sovereign and the embodiment of the natural body of the German people. The camps are the places where all rights are permanently suspended unto death in the name of the higher body of the state's exception. The camps, argues Agamben, are ultimately the nomos, the law itself. "Today," he says (181), "it is not the city but rather the camp that is the fundamental biopolitical paradigm of the West."

Hence, the subtle and astonishing line Agamben develops in the respective neglects of Foucault's biopolitics (no camps) and Arendt's human condition (no biopolitics). Political life is rooted not in membership but in zo', inbare life which draws no distinction between the categories of living beings. There is no difference between inclusion and exclusion. Bare life is the human condition. Homo Sacer is the state of political man who may be killed but not sacrificed — whose killing cannot be a homicide, whose being is indistinguishable from that of any other living thing. The modern democratic state establishes the writ of habeas corpus as the lie that protects its own life as the body of a people. The right to be present before the judiciary is the right to be judged by the state which ultimately possesses the right to suspend rights—-hence, the right to kill, the power over life, and death in the name of the state.

Agamben's ingenious interpretations are, in effect, comparable to Eco, the other, other Italian in that they are a theory of the lie of life that lies at the origin of the democratic state. It is not merely that state authority's lie-which they do-but they are founded on the lie that, in real terms everyone can appreciate for its dishonesty. The lie of the biopolitical State is that it is devoted to protecting life when it is actually more concerned with producing and policing death. So long as the modern democratic State floats on so weak a reed as the State's right to make exceptions, all who are excluded from citizenship_-like all who are included-will remain in roughly if not exactly the same position. The camp is the norm. In our time the millions living in refugee camps, the unknown numbers detained as political prisoners, the billions living as squatters, all the millions more of "undocumented workers" are all excluded by law from inclusion in political sphere the foundational lie of which is that those included are protected. The evidence of human history is to the contrary - that sooner or later the Sovereign will assert its right to protect itself to the exclusion of all rights to inclusion.

If the final lie is that life cannot ever be fully human in the sense that liberal humanism has insisted upon, then what are we to say of the staples of left politics — of liberation, of emancipation, of freedom, of speaking truth to power, of revolutions and resistances, and of all the rest? "The total humanization of the animal," says Agamben in The Open (77), "coincides with a total animalization of man." So long as the left continues to wed itself to the liberal romance of humanity's special nature, it will fail to acknowledge its (our) own animal nature, which is to say: our capacity to kill for life's sake, our willingness to suspend the laws of life, our animal-like propensity for cruelty that kills for no other reason than that it is our nature. The right is always willing and able to kill for power's sake. The lefts of our time are not. Power is biopower, power over life. The lie is that power can be gentle and reasonable. The truth is the absurd proposition that to live -- animals must kill and do. The lion cannot be called before a magistrate. Her killings are not homicides; nor are the religious sacrifices.

We who live and work in or on the bare margins of the academy are sometimes shocked by what goes on therein. It is one thing to be radical in the streets where windows are broken, heads are bloodied, where effigies are hanged and bodies beaten or killed outright. It is another, so say even we good folk of the academic left, to breach the rules of civil order. Everyone with eyes to see and heart enough to say it understands that colleges and universities are high on the list of the of liberal institutions willing to declare a state of exception to their own rules. Here is a short list drawn from the past few years of experience direct and indirect: 
- Leaders of a faculty union use their authority to quash a sex abuse complaint against one of them; the untenured woman who complained lost her position.

- An adorable young teacher uses his authority to vote down the work of students of a colleague he loathes; the students were denied the honors.

- Senior faculty at a prestigious English university, decided to shun a first-year student because he was thought to be on friendly terms with a faculty colleague they would like to kill; the student is called "the enemy" and soon departs the school.

- President of one of the nation's most liberal colleges demands that the local police arrest and jail students protesting at his office; mayor of the town refuses, saying they are kids, it is spring, no damage is being done; president brings internal charges against the kids.

I could go on. You could go on. These of course are symbolic killings, but they are murderous none the less. Life goes on in most cases. But then there are others where the life that goes on is put at risk, and the world loses something precious.

The case of another, other Italian is worthy of mention in this sad connection. Russell Jacoby, in a recent commentary in the Chronicle of Higher Education (June 13, 2008), recalls the story of Paul Piccone (1940-2004) at Washington University in St Louis. Piccone was the founding editor of Telos magazine which, before Polity Press in the UK entered the translating business, was the foremost source of news and texts of and by the leading European social theorists. It was also easily at the top of the list of intellectual lively and challenging journals -- and still is. The context for Paul's story is the long overdue publication in June, 2008, of a collection of Piccone's most important writings, Confronting the Crisis: Writings of Paul Piccone (Telos Press 2008). To read or reread the essays in this collection is to be reminded of what a truly modern version of Prison Notebooks might look like. The range of subjects—Gouldner, Gramsci, Jay, Marcuse, the New Left, Husserl, more and more-recalls not only the range of Paul's philosophical engagements but the astonishing precision of his interpretations.

I wrote one essay with Paul—a memorial tribute in Theory and Society to Alvin Gouldner. Paul and Al had been friends in the days when sociology at Washington University was in decline. Though both were in a kind of internal exile their two magazines, Telos and Theory and Society, were, together, the only games in town — and in the 1970s the only games in any leftish academic place. When Gouldner died, I was an editor at Theory and Society (which since has become a pale reflection of its founder's brilliance) and lived nearby. Thus, it fell to me to organize a few of the memorial matters, including a special issue of Theory and Society on $\mathrm{Al}$ for which Paul and I wrote on his reflexive method. Mind you, I was then under the sway of Gouldner's genius and had read everything he had written, including a good bit of manuscript he left behind. I knew Paul, but like many who knew him, kept him at arm's length for reason of his notoriously brutal honesty. What amazed me in the work was that Paul seemed to know and remember everything Gouldner had written—and to have a strong (not always favorable) understanding of the work. My amazement turned on the fact that when it came to serious and deep appreciation of Gouldner's thinking I, the devotee, could not touch the insight of Piccone, ever the gadfly. I was then young and callow if not quite narrow; Piccone, just three years my junior, was the master of so much more in so many languages from so many philosophical and theoretical traditions. His role in that one minor piece of his life's work was just one of the many digressions of a life lived confronting the liberal lies.

Russell Jacoby's tribute to Paul Piccone turns on the refusal of Washington University to grant him tenure. As Jacoby accurately states, Paul's case was exceptionally strong and was supported in positive and detailed letters by Habermas, among others of his international rank. (I saw the Habermas letter and know it to have been unqualified in its praise of the work. How I saw it—or how Paul got a copy of it—I do not recall—but the fact that he had it was indicative of his relentless pursuit of truths and lies.) Jacoby attributes Piccone's failure to be tenured to his aggressive truth-telling nature. It is true that Paul was the kind of friend who could share a drink in one instance, but in the next rise at a public conference to denounce you for your hopeless stupidity. Yet, the other side of the story is of the behavior of the administration in Paul's case.

Faced with an overwhelmingly strong case in the affirmative for an individual they wanted nothing to do with, the University, according to Paul, took the exceptional step of putting an economist who called himself Doug North in charge of the administrative review. North, who is said to have won a Nobel Prize in economics, was famously hostile to sociology in any of its manifestations. Whether it was North himself or the administration, or both, the tactic was to hire paid reviewers who would trash Paul's scholarly work. In the end, evidence to the contrary notwithstanding, the case was denied. Paul challenged in court, but lost. How could he have won in St Louis, then a two-company town, when Washington University, one of Ralston-Purina's virtually wholly-owned subsidiaries, 
demanded a judgment? I do not know what position, if any, Budweiser might have taken on the case, but it was clear that the dog food company controlled the board at the time when the university was in dire financial straits and insisted on its way.)

Today, there is no sociology at Washington University. Today, in many areas, it survives as a distinguished university. But it survives as a university and like liberal institutions everywhere that was willing and able to declare its own states of exception to its own rules. Today Paul Piccone would be labeled "uncivil" and the onus for his failures attributed to his manners. Yet, also today, and because of the other Italians, including Paul himself (and I mean his writings as well as his story), it is possible to consider the ruthlessness of the liberal lie that truth is truth and that the liberal state of affairs must be protected from homo sacer-those of bare life who can be killed without being sacrificed. Piccone took over my theory courses when I left Illinois, but Southern Illinois University in Carbondale was even less the place for him. Thence he made his way to New York City to resettle Telos for what it had become and remains today — a sometimes irritating, always aggressive, voice for contrariness in a murderous world. 
